DOI: https://doi.org/10.24127/ajpm.v10i4.4263

\title{
MATHEMATICAL LITERACY SKILLS USING GOOGLE CLASSROOM ON TRIGONOMETRY
}

\author{
Ari Septian $^{1 *}$, Destysa Maghfirah ${ }^{2}$ \\ ${ }^{1,2}$ Universitas Suryakancana, Cianjur, Indonesia \\ *Corresponding author. \\ E-mail: $\quad$ ariseptian@unsur.ac.id $^{1 *}$ \\ $\underline{\text { destymaghfi99@gmail.com }}^{2)}$
}

Received 21 September 2021 Received in revised form 16 November 2021; Accepted 15 December 2021

\begin{abstract}
The study aims at examining the improvement of students' mathematical literacy skills at the end of learning program after using Google Classroom (GC), analyzing students' final mathematical literacy skills using GC, and exploring students' respond in learning of using GC. One-Group Pretest-Posttest used as the design of this study. The population in this study was students of class X of SMA Negeri 1 Karangtengah Cianjur, the sampel was 20 students of X IPA 1. The sampling process is carried out using purposive sampling technique. The instrument used in the form of 3 items of mathematical literacy skill on trigonometric comparison material. The result shows that there is an improve in students' mathematical literacy skills after using GC. The achievement of indicators of students' mathematical literacy skills with GC media as a whole obtained a percentage of $71 \%$ which is included in the good criteria, with the highest achievement on the indicators of formulating problems. Students' response towards learning with GC as a whole earned a percentage of $69.58 \%$, which means most of the students responded positively. Based on this research, it can be concluded that there is an improve in students' mathematical literacy skills after using GC, the achievement of indicators of students' mathematical literacy skills with GC is in good criteria, and students' responses in learning mathematics with GC media are mostly positive.
\end{abstract}

Keywords: google classroom; mathematical literacy; trigonometry

\begin{abstract}
Abstrak
Tujuan penelitian ini adalah untuk mengkaji peningkatan kemampuan literasi matematis siswa di akhir pembelajaran setelah menggunakan media Google Classroom $(G C)$, menganalisis kemampuan literasi matematis akhir siswa dengan menggunakan media $G C$, dan menganalisis bagaimana respons siswa terhadap pembelajaran dengan menggunakan media GC. Desain yang digunakan dalam penelitian ini adalah One-Group Pretest-Posttest Design. Populasi dalam penelitian ini adalah siswa kelas X SMA Negeri 1 Karangtengah Cianjur, dengan sampel yang berjumlah 20 orang siswa. Proses pengambilan sampelnya dilakukan dengan menggunakan teknik sampling purposive. Instrumen yang digunakan berupa 3 butir soal kemampuan literasi matematis pada materi perbandingan trigonometri. Hasil penelitian ini menunjukkan bahwa terdapat peningkatan kemampuan literasi matematis siswa setelah menggunakan media GC. Pencapaian indikator kemampuan literasi matematis siswa dengan media GC secara keseluruhan diperoleh persentase sebesar $71 \%$ yang termasuk kedalam kriteria baik, dengan capaian tertinggi pada indikator merumuskan masalah. Respons siswa terhadap pembelajaran dengan media GC secara keseluruhan diperoleh persentase sebesar 69,58\% yang artinya sebagian besar siswa merespons positif. Berdasarkan penelitian ini dapat disimpulkan bahwa terdapat peningkatan kemampuan literasi matematis siswa setelah menggunakan media GC, dan pencapaian indikator kemampuan literasi matematis siswa dengan media GC berada pada kriteria baik, serta respons siswa terhadap pembelajaran matematika dengan media GC sebagian besar positif.
\end{abstract}

Kata kunci: google classroom; literasi matematis; trigonometri

This is an open access article under the Creative Commons Attribution 4.0 International License 


\section{INTRODUCTION}

In Indonesia, education is regulated in Law no. 20 of 2003 article 3 on SISDIKNAS (National Education System). Which emphasizes that the function of education is to develop the skills that exist in students, as well as to shape the character and civilization of a dignified nation in the context of educating the nation. So the function of education in Indonesia is not only to develop skills or potentials but also to shape character.

The level of education in Indonesia itself consists of Kindergarten (TK), SD, SMP, SMA, and Universities. From elementary school students are slowly taught to learn to read, write, and count. Counting itself is the basis of mathematics, which is an important subject to be mastered at all levels of education. Mathematics is a very important subject in human life because mathematics is the queen of science. The importance of Mathematics is reaffirmed by the Regulation of the Minister of National Education (PerMendiknas) Number 22 of 2006 that mathematics underlies the development of technological progress, mathematics has an important role in various disciplines, and advances the power of human thought (Idris \& Kristina Silalahi, 2016).

However, the majority of students usually mathematical literacy is complicated and difficult. Students with mathematical literacy skills are needed to model and interpret mathematical phenomena. The importance of literacy is also found in the setting of the teaching program from preKindergarten to grade 12 of NCTM, wherein the teaching program from pre-kindergarten to grade 12 must enable each student to: 1) Create and use literacy to organize, record or take notes, and communicating mathematical ideas; 2) selecting, applying, and translating mathematical literacy to solve or solve problems; 3) using literacy to model and interpret physical phenomena, social phenomena, and mathematical phenomena (NCTM, 2000).

Literacy is a person's skill to process and understand information when doing the reading and writing process (Sugiarto, 2020). Along with its development, the definition of literacy itself always evolves according to the challenges of the times. In the past, the definition of literacy was only limited to reading and writing, in this era the definition of literacy is starting to be used in a broader sense.

Kern (Masjaya \& Wardono, 2018) writes that literacy can be said to be the skill to read and write. This literacy is used in society (social) and historical and cultural situations in society in practice in creating and interpreting meaning (meaning) through a text. This requires at least mutual awareness, so that what we want to write will be understood by others without having to be explained again.

Several studies suggest the importance of mathematical literacy, including by R. H. N. Sari (2015) which writes that mathematical literacy skills are very important, because mathematics is closely related to everyday life (Fatwa, Septian, \& Inayah, 2019; Masjaya \& Wardono, 2018; Septian, Komala, \& Komara, 2019) writes that mathematical literacy skills are very important because it can improve human resources. human resources, mathematical literacy can help someone understand the use of mathematics in everyday life, for example buying and selling activities and others. Unfortunately, the mathematical literacy skill of students 
in Indonesia is still low, based on research from Khoirudin, Dwi Styawati, \& Nursyahida (2017), which writes that the profile of students' mathematical literacy skills with low mathematical skills can only reach level 1 of 6 levels of students' mathematical literacy skills.

In the research from Utaminingsih \& Subanji (2021) it was written that most students could only interpret mathematical results back to the real context without analyzing logical mathematical conclusions, most of the students had not used diagrams, graphs and mathematical constructions, and took mathematical information from them. In addition, judging from Indonesia's position in the Program for International Student Assessment (PISA) study initiated by the OECD (Organization for Economic Cooperation and Development) to measure global student learning competencies which is carried out every three years, in 2018 Indonesia was ranked third. 5 from bottom in math. Even in previous years, the results of the Indonesian score in the PISA study were not satisfactory, quoted from (Fazzilah, Effendi, \& Marlina, 2020).

In the era of the COVID-19 pandemic, students cannot carry out face-to-face learning at school so that the learning process becomes hampered (Abidah, Hidaayatullaah, Simamora, Fehabutar, \& Mutakinati, 2020). There needs to be a tool that can be used in carrying out online learning that makes it easier for the rest and teachers to continue learning (Iftakhar, 2016). There are several media that offer online applications that are used to support online learning in the classroom such as whatsapp, LMS, Schoology, and Google Classroom (GC) (Hidayat, Prasetiyo, \& Wantoro, 2019). One of the media used for the online learning process is to use GC (Wulandari, Hariadi, Jumadi, Wilujeng, \& Kuswanto, 2019). The advantage of GC is that teachers can interact in short messages, share audio documents, or videos of teaching materials, even those that have been prepared by the GC (Septian, Ramadhanty, Darhim, \& Prabawanto, 2021). In addition, the application of GC media to facilitate online learning is expected not to interfere with student learning outcomes but instead can maintain or even improve student interest in learning outcomes (Suanse \& Yuenyong, 2021). The weakness of GC occurs when the main facility is a weak internet network so that it becomes an obstacle in using GC media, especially assignments (Suryawan \& Permana, 2020).

Several studies related to mathematical literacy skills have been carried out by several researchers. Based on the results of research according to Rahmawati (2018), students' mathematical literacy skills can be improved through online-based learning with easy-to-use social media. Meanwhile, according to Anwar (2018), mathematical literacy skills who use elearning or online media, the results are better than those who do not use online media. Some researchers who use GC as an online learning media get results that their mathematical literacy skills improve because GC is the most effective medium during a pandemic (Shaharanee, Jamil, \& Rodzi, 2016). From several existing research results, researchers have not found research that discusses trigonometry material that students feel is difficult material and requires innovation in learning. Likewise, existing research has not focused on analyzing the improvement of mathematical literacy skills, achievement of indicators of 
mathematical literacy skills, and responses to learning with GC media.

Therefore, the researcher focuses on things that have not been previously studied by previous researchers. The objectives of this research is examining the improvement of students' mathematical literacy skills at the end of learning program after using GC, analyzing students' final mathematical literacy skills using GC, and exploring students' respond in learning of using GC.

\section{METHOD}

This research is an experimental study. That is, the method used in this study is an experimental method. In experimental research there is treatment. (Sugiyono, 2013). In this study there is an independent variable, namely learning media using e-learning with the Google Classroom application, while the dependent variable is students' mathematical literacy skill.

The type of research taken is Pre-Experimental Design (Sugiyono, 2013). The research design used is OneGroup Pretest-Posttest Design, in this design there is a pretest, before being given treatment. Thus the results of the treatment can be known more accurately, because it can compare with the situation before being treated (Sugiyono, 2013).

The population in this study were all students of class X SMA Negeri 1 Karangtengah in the even semester of 2020/2021. Meanwhile, the class selection as the sample was chosen by purposive sampling.This sampling technique using purposive sampling aims to produce a sample that can logically represent the entire population, namely sampling based on the characteristics or characteristics of the population that have been known previously, the characteristics and properties of which have been known by the mathematics teacher at the school so that the teacher gives one class as a sample with the same skill according to the teacher, the one choosen is class $\mathrm{X}$ IPA 1. The data collection technique of this research is to take data from the students' mathematical literacy test results at the beginning and at the end of the lesson. After that, collect data on student responses in the form of learning response questionnaires with GC media. The instrument used is a test of mathematical literacy skills and student response questionnaires to GC media. Data analysis used normality test, wilxocon test, and the percentage of students' answers.

\section{RESULT AND DISCUSSION}

From the pretest and posttest data, descriptive analysis was carried out to determine the class average of the sample, standard deviation, minimum value. The statistical descriptive results of the pretest and posttest data can be seen in the Table 1.

Table 1. Descriptive Statistics of Pretest-Posttest Score

\begin{tabular}{cccccc}
\hline Skor & N & Min & Maks & Mean & $\begin{array}{c}\text { Std. } \\
\text { Deviation }\end{array}$ \\
\hline Pretest & 20 & 2 & 12 & 4,90 & 2.614 \\
Posttest & 20 & 14 & 30 & 21,30 & 3.496 \\
\hline
\end{tabular}

From Table 1, it can be seen that the average final skill of students' mathematical literacy with GC media is higher than the initial skill of students' mathematical literacy. In addition, to obtain significant results, it is necessary to perform statistical tests on the data that has been obtained. Before testing the desired statistics, first perform a prerequisite test, namely the normality test of the data distribution. The normality test was conducted to 
determine whether the sample results were normally distributed or not. After the normality test, the average test of two samples was carried out.

The criteria for the normality test are if the significance value is > 0.05 then the data is normally distributed and if the significance value is $<0.05$ then the data is not normally distributed (Priyatno, 2012). From the calculation results, pretest data is not normally distributed because the significance value $=0.011<0.05$. Meanwhile, the posttest data were normally distributed because the significance value $=0.642>0.05$.

Because one of the results of the normality test of the data is not normally distributed, the data processing is continued with a nonparametric statistical test, namely the Wilcoxon test.

The test criteria are if the significance is $>0.05$, it can be said that there is no difference in students' mathematical literacy skills before and after using GC media, and if the significance value is $<0.05$ then there is a difference between the final mathematical literacy skill and the students' initial mathematical literacy skill using GC media (Priyatno, 2012). From the calculation results using Wilxocon test, sig. 2 tailed $=0.000<$ 0.05 . So, it can be concluded that there is a significant difference between the average final skill of students' mathematical literacy with GC media and students' initial mathematical literacy skill. This difference shows that students' mathematical literacy skills after using GC media are better. Because the final mathematical literacy skill of students after using GC media is better than the initial mathematical literacy skill. So, it can be said that there is an improve in students' mathematical literacy skills after using GC media.

The improve in students' mathematical literacy skills occurs because in the learning process using GC media it gives the teacher the flexibility to provide material both in the form of videos and ppt or pdf files. Students can also access it easily and only need an internet quota that is not too large to use. The use of GC media is also easily used by students from getting material, assignments, discussions, quizzes and others (Hidayat et al., 2019; Septian et al., 2021; Suanse \& Yuenyong, 2021). The forms of questions that are associated with trigonometry material are more understandable in terms of mathematical literacy.

Regarding the improvement of students' mathematical literacy skills, it is also in line with research Nabilah \& Wardono (2021), which states that by using GC, students can overcome their problems in receiving material and giving school assignments. The convenience that exists in GC media provides students with improving their mathematical literacy skills in algebraic material.

Table 2. Average Score of Mathematical Literacy Indicators

\begin{tabular}{lcc}
\hline \multicolumn{1}{c}{ Indicator } & Average & $\begin{array}{c}\text { Maximum } \\
\text { Score }\end{array}$ \\
\hline $\begin{array}{l}\text { Formulate the } \\
\text { problem }\end{array}$ & 7.2 & 9 \\
$\begin{array}{l}\text { Using facts, } \\
\text { concepts, } \\
\text { procedures and } \\
\text { reasoning in } \\
\text { mathematics }\end{array}$ & 8.35 & 12 \\
$\begin{array}{l}\text { Interpret ( } \\
\text { interpret ) } \\
\text { mathematics to } \\
\text { solve problems }\end{array}$ & 5.75 & 9 \\
\hline
\end{tabular}


DOI: https://doi.org/10.24127/ajpm.v10i4.4263

The results of this study are data obtained from the analysis of students' answers based on the reference guidelines for scoring students' mathematical literacy skills. The average score of students' mathematical literacy indicators is presented in the Table 2.

Looking at the average achievement scores of all indicators, the results of the calculation of the percentage of students' mathematical literacy achievement can be seen in the Table 3.

Table 3. Percentage of Achievement Indikator

\begin{tabular}{lcc}
\hline \multicolumn{1}{c}{ Indicator } & Percentage & Criteria \\
\hline $\begin{array}{l}\text { Formulate the } \\
\text { problem }\end{array}$ & $80 \%$ & Well \\
$\begin{array}{l}\text { Using facts, } \\
\text { concepts, } \\
\text { procedures and } \\
\text { reasoning in } \\
\text { mathematics }\end{array}$ & $69.58 \%$ & Enough \\
$\begin{array}{l}\text { Interpret ( } \\
\text { interpret ) } \\
\text { mathematics to } \\
\text { solve problems } \\
\text { Average }\end{array}$ & $63.89 \%$ & Enough \\
\hline
\end{tabular}

Based on Table 3 the average percentage of students' mathematical literacy skills in formulating problems mathematically in indicator 1 is $80 \%$, it means that students' skill to formulate problems with good criteria, some students have been able to formulate problems correctly although there are still a few mistakes when formulating problems mathematically. In indicator 2, namely using facts, concepts, procedures and reasoning in mathematics, the percentage of achievement indicators is $69.58 \%$, it means that students' skill to use facts, concepts, procedures, and reasoning in mathematics is classified as sufficient.
In indicator 3, the percentage of the skill to interpret (interpret) mathematics to solve problems is $63.89 \%$ belonging to the sufficient criteria. Based on the percentage of the three indicators, the average achievement of the indicators of mathematical literacy skill is $71 \%$ or is in the good category. So the achievement of students' mathematical literacy skills with GC media has good criteria.

Based on the overall research results, after using GC media in learning mathematics, it can improve students' mathematical literacy skills. This can be seen from the category of students' skill to identify strategies that can be taken from each indicator that has good criteria. This can solve a problem in the form of story questions, especially on Trigonometric Comparison material.

In the discussion about improving students' mathematical literacy skills using GC media, this is in line with the research who said that by using GC learning would be easier to realize, because it has advantages such as making classes fast, saving and time efficient, and also able to improve cooperation and communication so as to improve students' mathematical literacy skills (Nabilah \& Wardono, 2021).

In line with other research which states that the indicator of students' mathematical literacy ability is categorized as good or reaches $74.56 \%$. The indicators that contributed the most were using facts, concepts, procedures and reasoning in mathematics with a percentage of $81.34 \%$ (Sudarman, Sartika, Sugiharta, \& Farida, 2021). It is also in line with other research which states that the achievement of indicators of mathematical literacy ability is in the good category after receiving learning on fractional material (Aziza, 2021). 
DOI: https://doi.org/10.24127/ajpm.v10i4.4263

Based on the percentage of achievement of the indicators of mathematical literacy scores of pretest and posttest, the comparison between pretest and posttest of mathematical litaracy skill can be seen in Figure 1.

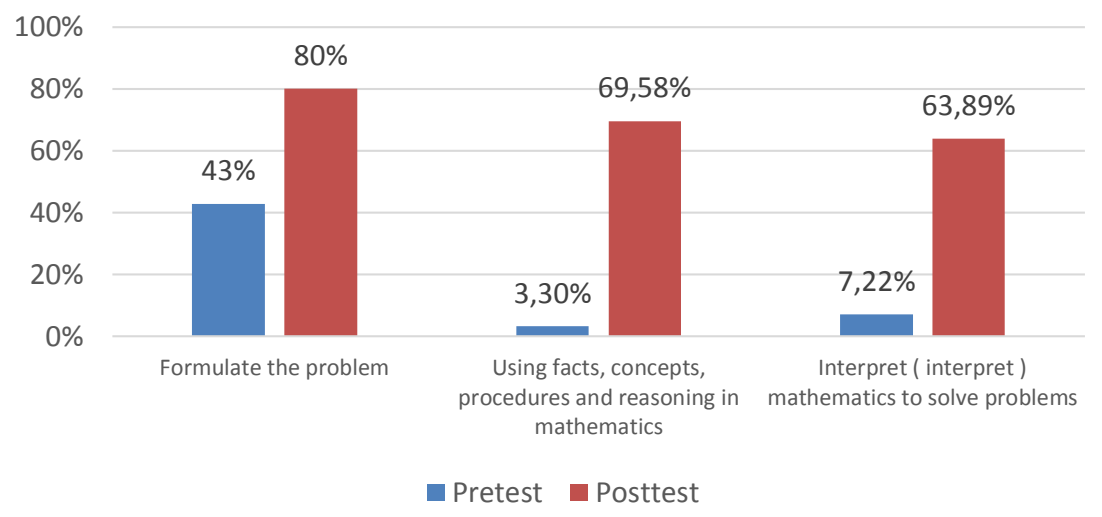

Figure 1. Comparison of the percentage of achievement of students' mathematical literacy skills indicators

In Figure 1, there is a very significant improve in the percentage of achievement indicators of students' mathematical literacy skills from the pretest and posttest, it can be seen that the difference in the percentage of achievement in each indicator shows an improve after learning using GC. In indicator 1 is $37 \%$. The difference in the percentage of achievement of indicator 2 on pretest and posttest is $66.28 \%$, and the difference in achievement of mathematical literacy indicators on indicator 3 on pretest and posttest is $56.67 \%$.

In addition to students' mathematical literacy skills, the use of GC also affects students' mathematical problem solving skills based on research (Sudarman et al., 2021) which says that based on the results of his research, the key to the influence of GC-assisted courage-based learning on mathematical problem solving skills.
The statements in the questionnaire contain student attitudes related to $\mathrm{GC}$ as a learning medium during the COVID 19 pandemic. The following is the frequency of student answers after being calculated and interpreted on each statement indicator which has been grouped into 2 types of attitudes, namely positive attitudes and negative attitudes, then calculated using the student statement answer mode calculation.

Overall, the average student response to learning using GC media $(69.58 \%)$ showed a positive attitude. Based on the average statements of each indicator of student responses to learning mathematics with GC media, it can be concluded that the use of GC as a learning medium in mathematics subjects during the COVID-19 pandemic was mostly positive. The percentage of student responses to learning mathematics with GC media can be seen in the Figure 2 . 
DOI: https://doi.org/10.24127/ajpm.v10i4.4263

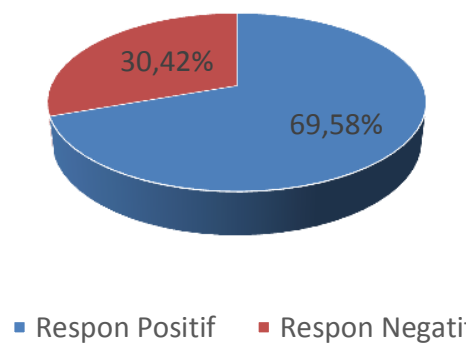

Figure 2. Diagram of the percentage of student responses to learning with GC media

Based on Figure 2, the percentage of students who responded positively to learning with GC media was $69.58 \%$, meaning that around 14 out of 20 students stated that GC learning media was easy to use, had benefits in learning, had good service quality, had risks. low, and effective for use in learning mathematics.

To find out student responses to learning using GC media, data processing in the form of questionnaires was carried out. The data obtained from the results of the questionnaire responses to student responses to learning using GC media were given after 2 meetings. The results of student answers are based on indicators adapted from indicators of the effect of using GC on the effectiveness of student learning at the Islamic University of Indonesia (I. N. Sari, 2019) which consists of the ease of $\mathrm{GC}$, the benefits of GC, the quality of GC services, the use of GC, and the effectiveness learning with GC media.

Based on the questionnaire analysis of students' responses to GC on each indicator, data is obtained that for the first indicator most students respond positively, meaning that GC is easy to use in learning mathematics. In the second indicator, most of the student responses were positive, meaning that GC provided benefits in learning mathematics. In the third indicator, most of the student responses were positive, meaning that the quality of GC services during learning was good. In the fourth indicator, most of the student responses were positive, meaning that the use of GC was good. Even though the statement number 20 is "The risk of using GC is low, so I will continue to use GC in the future". In this statement, the positive attitude of students is only $30 \%$ and the negative attitude is $70 \%$. This is due to the system failure experienced by students when uploading their assignments, making students think that the risks of using GC are quite disturbing. But overall the GC system is quite stable, it's just that the timing of the research coincided with the maintenance of Google services so that the GC system was also affected. In the fifth indicator, most of the student responses were positive, meaning that the use of GC during online learning during the COVID-19 pandemic could be said to be effective. So overall student responses to learning with GC media are mostly positive, this is because GC has many advantages including a simple and functional appearance so that students do not find it difficult to learn how to use GC. This is in line with research I. N. Sari (2019), which states that the results of his research show a positive response for 
each indicator. The results of this study are also in line with research Shaharanee et al. (2016) which concludes that overall respondents are satisfied with learning activities using GC, specifically respondents are satisfied with the ease of access, usskill, and communication and interaction presented by GC. In addition, his article Iftakhar (2016) also reveals that the results of the questionnaire analysis indicate that his research is effective in understanding and evaluating the perspectives of teachers and students to emphasize the quality of teaching and learning through GC.

\section{CONCLUSION AND SUGGESTION}

Based on the results of research and discussion, it can be concluded that there is an improve in students' mathematical literacy skills after using GC media. 2. The achievement of students' mathematical literacy indicators with GC media is good; 3 . Student responses to learning with GC media are generally positive.

Suggestions for future researchers are to maximize the use of GC media, prepare all materials in the form of videos, evaluation tools, material files, and discussions. The videos made are suggested to be made by the teacher himself so that he can adjust to the needs or interests, the material used may be trigonometric material or other material in mathematics.

\section{REFERENCES}

Abidah, A., Hidaayatullaah, H. N., Simamora, R. M., Fehabutar, D., \& Mutakinati, L. (2020). The Impact of Covid-19 to Indonesian Education and Its Relation to the Philosophy of "Merdeka Belajar." Studies in Philosophy of Science and Education, 1(1), 38-49. https://doi.org/10.46627/sipose.v1i 1.9

Anwar, N. T. (2018). Peran Kemampuan Literasi Matematis pada Pembelajaran Abad 21. Jurnal Prisma, 1, 364-370.

Aziza, M. (2021). Online Learning during Covid-19: What is the Most Effective Platform for Teaching and Learning Mathematics? Edumatika: Jurnal Riset Pendidikan Matematika. https://doi.org/10.32939/ejrpm.v4i 1.754

Fatwa, V. C., Septian, A., \& Inayah, S. (2019). Kemampuan Literasi Matematis Siswa melalui Model Pembelajaran Problem Based Instruction. Mosharafa: Jurnal Pendidikan Matematika, 8(3), 389-398.

Fazzilah, E., Effendi, K. N. S., \& Marlina, R. (2020). Analisis Kesalahan Siswa Dalam Menyelesaikan Soal Pisa Konten Uncertainty dan Data. Jurnal Cendekia: Jurnal Pendidikan Matematika, 4(2), 1034-1043. https://doi.org/10.31004/cendekia. v4i2.306

Hidayat, M. L., Prasetiyo, W. H., \& Wantoro, J. (2019). Pre-service student teachers' perception of using google classroom in a blended course. Humanities and Social Sciences Reviews. https://doi.org/10.18510/hssr.2019. 7242

Idris, I., \& Kristina Silalahi, D. (2016). Penerapan Pendekatan Pendidikan Matematika Realistik Indonesia (PMRI) untuk Meningkatkan Kemampuan Penyelesaian Soal Cerita pada Kelas VII A SMP UTY. Jurnal EduMatSains. 
Iftakhar, S. (2016). Google classroom: what works and how? Journal of Education and Social Sciences, 3, 12-18.

Khoirudin, A., Dwi Styawati, R., \& Nursyahida, F. (2017). Profil Kemampuan Literasi Matematika Siswa Berkemampuan Matematis Rendah Dalam Menyelesaikan Soal Berbentuk Pisa. Aksioma, $8(2)$, https://doi.org/10.26877/aks.v8i2.1 839

Masjaya, \& Wardono. (2018). Pentingnya Kemampuan Literasi Matematika untuk Menumbuhkan Kemampuan Koneksi Matematika dalam Meningatkan SDM. PRISMA, Prosiding Seminar Nasional Matematika, 568-574.

Nabilah, F., \& Wardono, W. (2021). Kemampuan Literasi Matematis dengan Higher Order Thinking pada Pembelajaran CIRC Bernuansa SPUR Berbantuan Google Classroom. PRISMA, Prosiding Seminar Nasional ..., 4, 200-207.

NCTM. (2000). Principles and Standards for School Mathematics. In School Science and Mathematics (Vol. 47). Retrieved from www.nctm.org

Priyatno, D. (2012). Cara kilat belajar analisis data dengan SPSS 20. In Yogyakarta: Andi Offset.

Rahmawati, N. I. (2018). Pemanfaatan ICT dalam Meningkatkan Kemampuan Literasi Matematika. PRISMA, 1, 381-387.

Sari, I. N. (2019). Pengaruh Penggunaan Google Classroom Terhadap Efektifitas Pembelajaran Mahasiswa Universitas Islam Indonesia. 1-120.
Sari, R. H. N. (2015). Literasi Matematika: Apa, Mengapa dan Bagaimana? Matematika Dan Pendidikan Matematika UNY 2015, 713-720. Yogyakarta.

Septian, A., Komala, E., \& Komara, K. A. (2019). Pembelajaran dengan Model Creative Problem Solving (CPS) untuk Meningkatkan Kemampuan Berpikir Kreatif Matematis Siswa. Jurnal Prisma Universitas Suryakancana.

Septian, A., Ramadhanty, C. L., Darhim, D., \& Prabawanto, S. (2021). Mathematical Problem Solving Ability and Student Interest in Learning using Google Classroom. Prosiding International Conference on Education of Suryakancana, 1(1), 155-161.

Shaharanee, I. N. M., Jamil, J. M., \& Rodzi, S. S. M. (2016). The Application of Google Classroom as a Tool for Teaching and Learning. Journal of Telecommunication, Electronic and Computer Engineering, 8(10), 8-11.

Suanse, K., \& Yuenyong, C. (2021). Development of the analytic geometry flipped classroom teaching model through Google Classroom. Journal of Physics: Conference Series. https://doi.org/10.1088/17426596/1835/1/012077

Sudarman, Sartika, Sugiharta, I., \& Farida. (2021). Pengaruh ELearning Berbantuan Google Classroom Terhadap Kemampuan Pemecahan Masalah Matematis. 05(03), 2133-2140.

Sugiarto, A. (2020). Peningkatan Literasi Bahasa Indonesia Tentang Menulis Melalui Pembelajaran Brainstorming. 
DOI: https://doi.org/10.24127/ajpm.v10i4.4263

Sugiyono. (2013). Metode Penelitian Pendidikan Pendekatan Kuantitaif, Kualitatif, dan R\&D. https://doi.org/10.1. Metode Penelitian Pendidikan Pendekatan Kuantitaif, Kualitatif, Dan $R \& D$. https://doi.org/10.1007/s13398014-0173-7.2

Suryawan, I. P. P., \& Permana, D. (2020). Media Pembelajaran Online Berbasis Geogebra sebagai Upaya Meningkatkan Pemahaman Konsep Matematika. Prisma, 9(1), 108.

https://doi.org/10.35194/jp.v9i1.92 9

Utaminingsih, R., \& Subanji, S. (2021). Analisis Kemampuan Literasi Matematika Peserta Didik Pada Materi Program Linear Dalam Pembelajaran Daring. ANARGYA: Jurnal Ilmiah Pendidikan Matematika, 4(1), 28-37. https://doi.org/10.24176/anargya.v $4 \mathrm{i} 1.5656$

Wulandari, Hariadi, M. H., Jumadi, Wilujeng, I., \& Kuswanto, $\mathrm{H}$. (2019). Improving Mathematical Representation Ability of Student's Senior High School by Inquiry Training Model with Google Classroom. Journal of Physics: Conference Series, 1233(1). https://doi.org/10.1088/17426596/1233/1/012043 